\title{
Local Political Power and Social Protection Policies for Elderly People in the Portuguese Context - An Exploratory Study
}

\author{
Cezarina Maurício
}

Master of Social Work/Specialist of Social Work

Higher School of Education and Social Sciences, Politechnic of Leiria

\section{Liliete Matias}

Higher School of Education and Social Sciences, Politechnic of Leiria

\section{Doi: $10.19044 /$ esj.2021.v17n26p60}

Submitted: 08 April 2021

Accepted: 08 June 2021

Published: 09 August 2021
Copyright 2021 Author(s)

Under Creative Commons BY-NC-ND

4.0 OPEN ACCESS

Cite As:

Maurício C. \& Matias L. (2021). Local Political Power and Social Protection Policies for Elderly People in the Portuguese Context - An Exploratory Study. European Scientific Journal, ESJ, 17 (26), 60. https://doi.org/10.19044/esj.2021.v17n26p60

\section{Abstract}

Since the Carnation Revolution in April of 1974, and the consequent approval of the Portuguese Republic Constitution (1976), the country's legislative trend has been geared towards the expansion of local government power, in Portugal. This issue has acquired new relevance recently, with the new reconfiguration of the political decentralization process, through Law No. $50 / 2018$, of $16^{\text {th }}$ August. This is a gradual process, still ongoing, and delayed by the current pandemic situation. Local authorities play a decisive role in the country's development, both in the present and in the past. Initially focused on creating essential and basic infrastructures for the people, now includes other concerns, such as social protection. The definition and implementation of social policies, targeted to different populations, has become an essential axis of action, in a country marked by territorial disparities and an aging population. This study aims to understand the role of local administration in the characterization of social policies targeted at senior populations. The present work is a study of qualitative and explorative nature. Using documentary research and content analysis, we identified and characterized the measures aimed at the senior population implemented by two 
municipalities (Gouveia and Ourém). The analysis of the results allows us to conclude that the municipalities implemented measures that target the elderly population directly. Seniors also benefit from other measures, applicable to other age groups. It is important that the discussion focuses on these measures and the achievement of their goals. Measures to protect the elderly population are urgent, especially in a southern European country like Portugal, that has an ageing population, with a considerable increase in people aged 65 and over.

Keywords: Local Power; Social politics; Ageing

\section{Introduction}

\section{Theoretical Framework}

As a centralized country, the Local Political Power of Portugal has been asserting itself in the public administrative framework. It has been a long way since the $25^{\text {th }}$ of April of 1974, to the situation we are experiencing today. The analysis of the specific legislation on the subject allows us to conclude that there have been adjustments in the national political organization, both in terms of the appropriation of competences and in terms of financing, gradually giving more power to municipalities.

The first information presented in the literature acknowledges the emergence of the Portuguese municipalism. Thus, it is considered that the local administration in Portugal dates to the beginning of the nationality. However, it is also mentioned that throughout national history, municipalities have experienced more and less political autonomy and management capacity (Ruivo, 1990). ${ }^{1}$

The revolution of April $25^{\text {th }}$ of 1974 , which reimplemented democracy in Portugal, was a major milestone in the development of the local administration (Veneza, 1986; Ruivo,1990; Mozzicafreddo et al,1991;). It can be considered that the local power was created, and above all, empowered by the 1976 Constitution.

The democratic organization of the State now incorporates the local authorities. These local authorities are endowed with representative bodies that search the specific interests of the respective population. Local authorities are defined as "territorial legal persons with representative bodies, which aim to pursue the interests of their respective populations" ( $\left.\operatorname{art}^{\circ} 235 \mathrm{CRP}\right)$.

The introduction of democracy in Portugal, presumes the decentralization of power, the participation of citizens in the local administration, and the encouragement of regional power. This was considered an innovative aspect of the new democratic Constitution, as there

\footnotetext{
${ }^{1}$ As an example of this antiquity, the so-called Concillium Vicinal (assembly of neighbors) from the "Reconquista" period are presented, which constituted themselves as the first organ of local power.
} 
was a complete rupture with the notion of local government structures that prevailed in the previous Portuguese political period, a dictatorship named "Estado Novo". Mozzicafreddo et al (1991, p.52) declares that "in addition to the control carried out through the regime of indirect representativeness and dependence on central organs, the dependence and control of local finances completed the inability of autonomy of the municipalities during the "Estado Novo"'.

As mentioned before, the Constitution of the Portuguese Republic preserves decentralization, as well as financial autonomy for the municipalities that are entitled to their own assets and finances. According to Cardoso (2012), in 1977 was published one of the essential laws to the Local Government - the $1^{\text {st }}$ Law of Local Authorities - which established the first framework of competences of the municipalities and of their organs. These tasks included the administration of own and under jurisdiction, public supply, culture and personal assistance, public health among others (Menezes, 2002). The analysis of the framework of the tasks of the municipalities is important in order to become aware of the limitations, as well as of the possibilities of expansion of their intervention. In 1979, the municipalities began to have administrative and financial autonomy, outlined by the $1^{\text {st }}$ Local Finance Law (Law No. 1/79 of January 2).

The Decree Law No. $100 / 84$ of $29^{\text {th }}$ March, constitutes a broader structure of attributions of competences of municipalities, especially in the social field, being therefore one of the most relevant legislation in the attributions and competences of local authorities. This legislation, constituting the first revision to local legislation, has enshrined the area of health as a generic attribution of local authorities. In addition to health, education, culture, sport and leisure are foreseen. The following year, through Law 25/85, of $12^{\text {th }}$ August, the competences of local authorities in the social area were increased with the protection of children and the elderly.

The field of social action joins the competences of the municipalities through the diploma dated to 1999 . Thus, the Law No. 159/99 of $14^{\text {th }}$ September establishes the framework for transfers of power to local authorities and clarifies the competences of municipalities, in article 13. An increase in the competences is considered, especially social action and housing. In the case of social action, it should be stated that municipalities become part of local social action councils and are obligatorily heard regarding public investors and action programs to be developed within the municipality.

The municipalities are also responsible for participating, in cooperation with IPSS's ${ }^{2}$ and in partnerships with the Central Administration, in programs and projects of social action at the municipal level. In particular, in the fields of combating poverty and exclusion. Article 23 also clarifies that municipal organs can ensure equipment management and make investments 
in social facilities such as day care centers for the elderly and others. Indeed, this law has strengthened the social component in municipalities.

After more than a decade, a new legal provision has been approved. This is Law No. 75/2013, of $12^{\text {th }}$ September, which establishes the legal regime for the transfer of powers from the State to local authorities and to inter-municipal entities and approves the legal regime for municipal associations. Regarding municipalities, it maintains the competences in the domains of rural and urban equipment; energy; transport and communications; education; cultural heritage, culture and science; health; housing, social action; civil protection; environment and basic sanitation; consumer defense; promotion of development; spatial planning and urbanism; municipal police; and external cooperation. The key element of this law is found in the emergence of the so-called inter-municipal communities whose nature, functions and status are subject to critical analysis. In fact, they seem to be created to lead us to forget the regions, foreseen in the $\mathrm{CRP}^{3}$ and never created. They assemble municipalities from different districts, disregarding that the district is the administrative unit with correspondence to the constituencies in force.

The administrative decentralization of local government gains new contours through the approval of Framework Law No. 50/2018, of August $16^{\text {th: }}$ transfer of competences to local authorities and to intermunicipal entities, implementing the principles of subsidiarity, administrative decentralization and autonomy of the local government. The central executive power bases this commitment on the recognition that local authorities are the fundamental structure for the management of public services, due to its proximity to the population. This is an argument most often referred to as a strong point of local power (Veneza, 1986; Ruivo, 1990; Mozzicafreddo et al, 1991;).

In addition, the quality of access to public services, territorial cohesion and the guarantee of universality and equal opportunities in access to public services are mentioned in article 2. With regard to social action, the broadening of responsibilities is notorious, incorporating some functions currently exercised by other bodies of the central public administration, such as the case of social security (article 12). But the complexity of this process, both in terms of the nature of the competences and in terms of financial issues, requires the publication of legislative diplomas that materialize the transfer in different domains. Despite acknowledging the need for this process of transferring competences to local authorities (and to intermunicipal entities), which had been announced for some time, the debate was installed among local elected representatives and different perspectives proliferated.

Local authorities played an important role in economic and social development of their communities. It was important, in a context of affirmation of democracy, of low levels of economic and social development, 
of regional asymmetries. For more than a decade, an investment has been made in creating basic infrastructures and in acquiring indispensable equipment at the local level. The different legislative modifications allowed for the incorporation of new competences, namely in the social area.

In Portugal, the State central and local) had and still has a decisive role in defining and implementing public social policies. This role of provider of public goods and services and of welfare, as well as recognition of social rights takes place after 1974. Although there are principles shared by all the countries that make up the European Union (Hemerijck, 2002), it is also a fact that they manifest themselves in different ways, both in institutional and political terms. Therefore, diversity is perhaps the strongest distinguishing mark of the social policy of member states. It is these differences that allow us to identify three dominant models of the welfare state in Europe - the social- democratic, the corporate and the liberal (Esping - Andersen, 1990) ,which can be five, if we consider two others that correspond more to geographical spaces than to dominant political principles - that of Southern Europe (Ferrera, 1996) and that of the enlargement countries to the East (Guillén \& Palier, 2004). Portugal is, without a doubt, in the "model" of the countries of Southern Europe.

The evolution of the assertion of local power and its responsibilities is accompanied by discussions, setbacks, difficulties and ambiguities, translated into different dimensions (Mozzzicafreddo et al, 1991). According to the authors, this finding is present in the legislation itself and in its application, it is visible in the endowment and financial autonomy and in the relationship between central administration and local government. The process of transferring and readjusting competences is a difficult and slow process, both by its nature and by the nature of the functions to be transferred.

In a context of globalization, municipalities have an increasing importance in the quality of life of citizens, due to their proximity and ability to provide quick responses that meet the needs in different aspects, including social policies. Currently, social policies are undergoing significant pressure, which provides the Local Government with new paradigms of intervention in different issues and with different groups, including seniors. Local action is thus seen as a strategy that encompasses several social actors involved in projects and initiatives at the local level, carried out in isolation or in a network, and can be seen as a local application of public policies.

\section{Municipalities characterization}

The Portuguese municipalities we chose to carry out this study were Ourém and Gouveia, both belonging to the Central Region (NUTSII) of Portugal. Ourém is a Sub-Region of "Médio Tejo", and Gouveia a Sub-Region 
of "Beiras and Serra da Estrela", therefore needing a comparative characterization of both counties.

Ourém has an area of $416,55 \mathrm{~km}^{2}$, and is located near the West Coast, between Lisbon and Coimbra. Gouveia has an area of $300,61 \mathrm{~km}^{2}$, and is located in the interior of Portugal, next to "Serra da Estrela", the largest Portuguese mountain range. Both are in the Central Region of Portugal.

We can verify, through the data obtained in Pordata, that the evolution of the population of both counties follows the trend registered in Portugal, that is, there is a significant decrease in the population. In Portugal, in 2010 there were 10573100 inhabitants; and in 2019 there were 10286263 inhabitants a difference of 286837 inhabitants. In Ourém, in 2010, there were a total of 46071 inhabitants and Gouveia had 14212 inhabitants. Nine years later there was a decline, as seen in the country as a whole: less 2015 habitants in Ourém (44 056) and less 1775 habitants in Gouveia (12 437). (Pordata, 2021), as we can see through the next graphic.

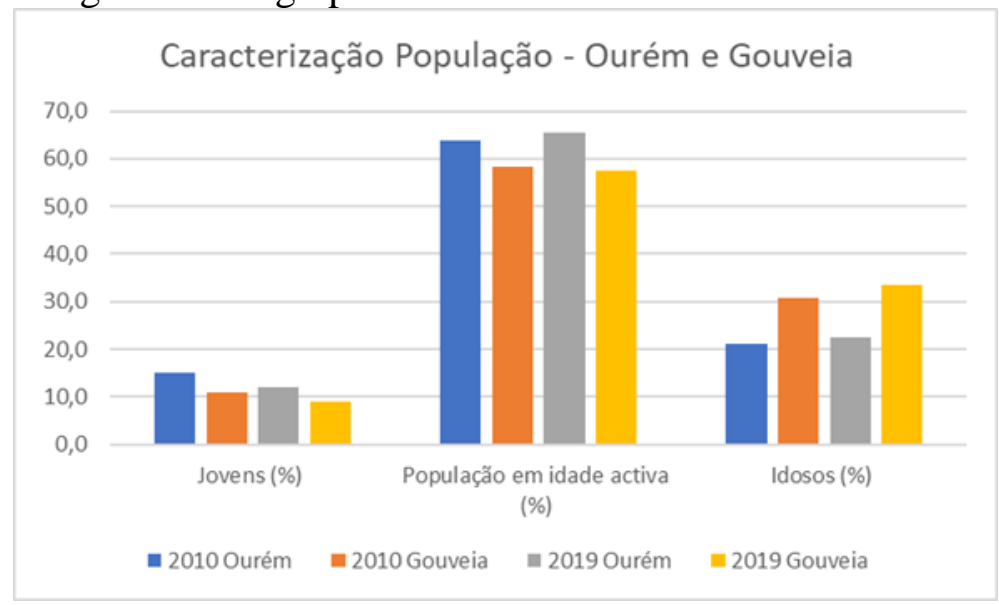

Figure 1 - Ourém and Gouveia population

Source: Authors

In 2010, the population of Ourém was composed of $15 \%$ young people, and in 2019, there was a decrease of 3\%. The same phenomenon was observed in Gouveia: in 2010 the population was $10.9 \%$ young people and in 2019 we observed a decrease of $2 \%$ of young people $(8.9 \%)$.

Regarding the active population, the municipalities under analysis underwent different changes. While in Ourém there was a growth of $1.7 \%$ from $2010(63.9 \%)$ to 2019 (65.6\%), in Gouveia there was a decrease of $0.9 \%$ from $2010(58.4 \%)$ to $2019(57.5 \%)$.

In the elderly population, we observed an increase in both municipalities. In Ourém there was a growth of 1.4\%: in 2010, $21 \%$ of the population was elderly, and in 2019 it rose to $22.4 \%$. In Gouveia this growth 
was more substantial, from $30.7 \%$ of elderly population in 2010 to $33.6 \%$ in 2019.

Regarding the aging and longevity index (Figure 2), we can conclude that the alterations in the elderly population were similar in both municipalities: there was a significant increase in the elderly population. The longevity also increased in both Ourém and Gouveia.

In Ourém, in 2010, there was a longevity index of 50.5\% and in 2019 there was an index of 54.3\%; an increment of 3.8\%. In Gouveia, the growth was of $2 \%$, from a longevity index of $54 \%$ in 2010, to $56.8 \%$ in 2019 .
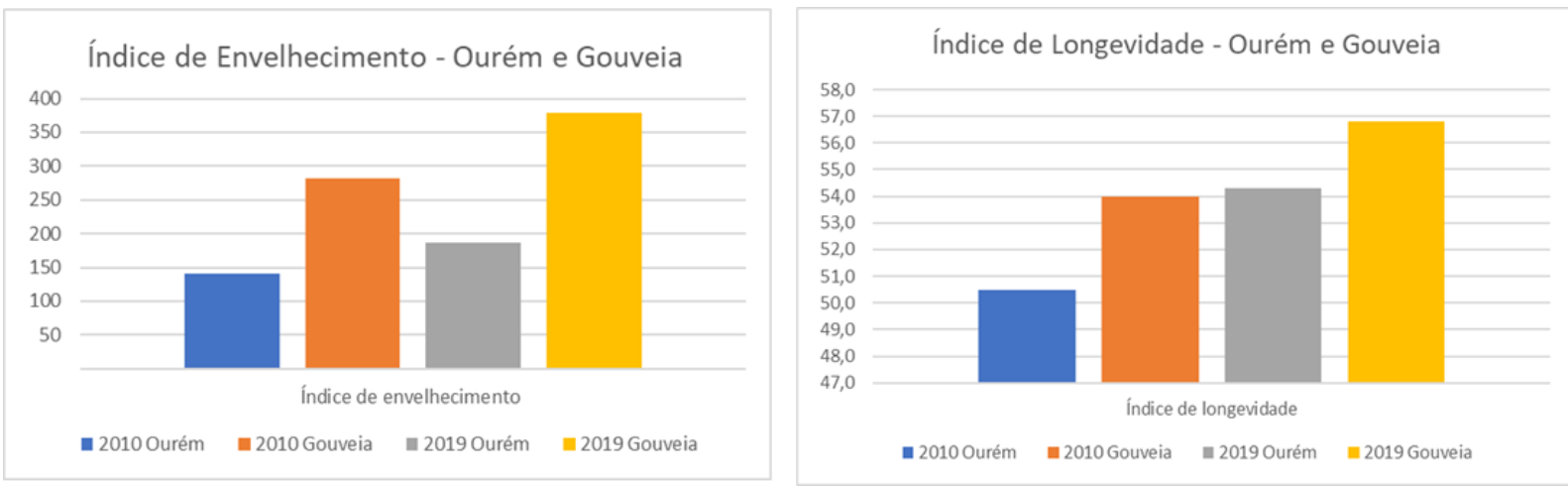

Figura 2 - Ageing and Longevity Index

Source: Authors

It is important to analyze the average life expectancy at birth and the average life expectancy at age 65 . According to the site "Pordata", this data also increased in the Central Region of Portugal.

The average life expectancy in 2010 was 79.1 years, and in 2018 it was 81.2 years; there was an increase of 2.1 (two years and one month).

The average life expectancy at 65 has also increased. In 2010 the population over 65 would still have, on average, more than 18.9 years to live. In 2018, they had an average of 19.8 years.

We can conclude, through the socio-demographic analysis of both municipalities, that the population has been aging; a trend that is similar in Portugal and in most countries.

Faced with this reality, it is increasingly needed to develop social answers, alternatives through policies and programs of intervention in the elderly.

\section{Methodological Framework}

The present work is a study of qualitative and explorative nature. Starting from the attributions and competences of the local municipalities, namely in the social area, this study aims to understand the role of local 
authorities and its importance in the characterization and development of social policies targeted at senior populations.

As specific objectives, this study aims to identify the area of social action in the organic structure of the municipality; analyze the measures aimed at seniors implemented by the municipalities; capture the existing articulation between the municipalities with the central public administration and with the Private Social Solidarity Institutions of the Municipality.

The non-probabilistic sample, for convenience purposes, consisted of two municipalities chosen based on researchers' knowledge, proximity and attendance of the activities promoted by these municipalities.

Documentary research was selected as the data collection technique, and the basis of this work was the information on municipalities' website and the management report for the year 2019. It should be noted that the management report for the year 2020 will only be presented at an ordinary meeting of the municipal assembly scheduled for the month of April.

We considered that this choice provides adequate information, in accordance to the outlined objectives. The analysis of the material required the consequent codification, categorization and quantification. The collection of information was carried out in the period between September $27^{\text {th }}$ and October $27^{\text {th }}$ of 2020 .

First, a reading/exploration of the referred documents was carried out. This task permitted an initial contact through which it was possible to obtain first impressions, facilitating the recognition of the information exposed and worked on.

The analysis and coding procedures of the content of the documents were carried out guided by a Grounded Theory posture. That is, from the units of analysis, categories/subcategories emerged that were continuously compared with each other and from which resulted the domains and categories presented in the results. (Glaser \& Strauss, 1967). Coding procedures go through several stages in which the constant comparison of categories and questioning of data plays a fundamental role.

In the absence of previously defined categories, the data was around certain areas that reflect the type of responses/reactions adopted/implemented by the municipalities. Presented below is the scheme that guides the collected and analyzed data (Figure 3).

The emerging categories and the construction of the framework were organized into four domains. It should be noted that it was decided to present the common categories: the categories that appear in all documents (Hill, Thompson \& Williams, 1997). 

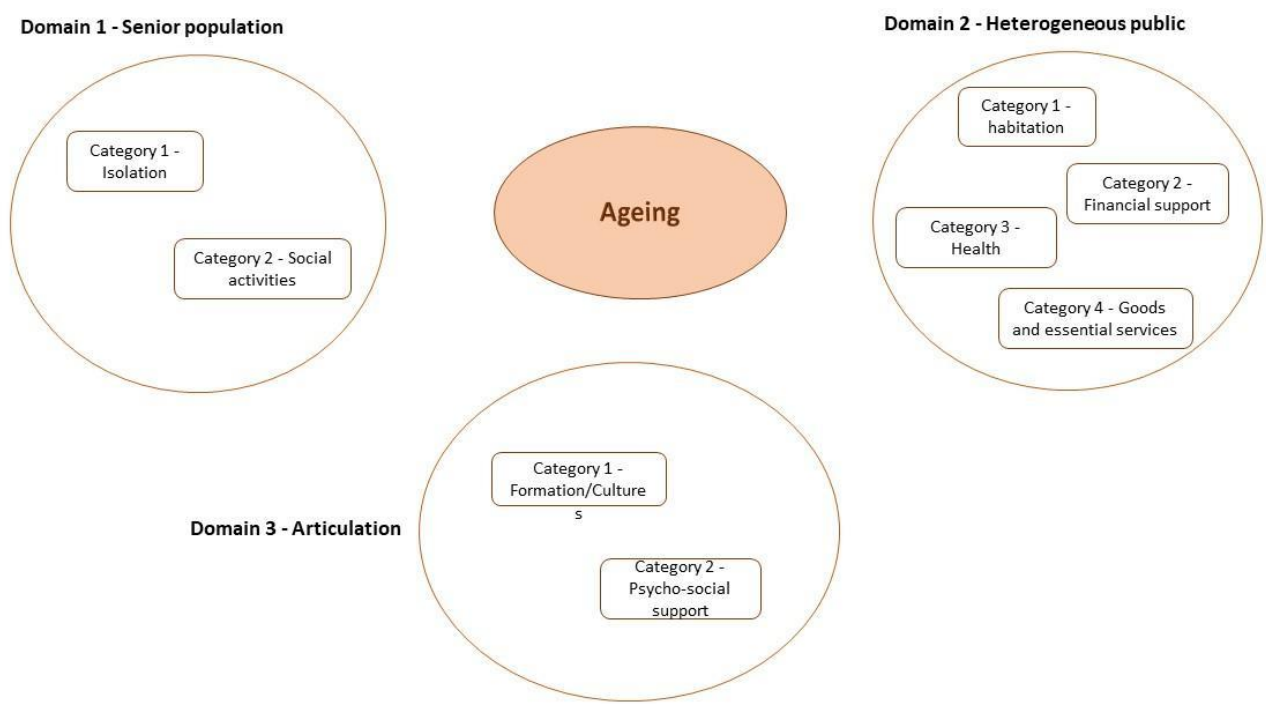

Figure 3 - Domains and categories of analysis Source: Authors.

The following domains were defined:

Domain 1- Senior Population: this domain includes measures adopted by municipalities directly for the senior population.

Category 1 - Isolation: actions/services aimed to prevent isolation, promote safety and keep seniors in their respective homes, through technological devices (teleassistance) and on-demand transport.

Category 2 - Social activities: carrying out activities/events that celebrate traditional festivities (Christmas in nursing homes, senior carnival), milestones known to be linked with the senior population (eg International Elderly Day, Grandparents' Day) or that promotes their involvement - museum party day for seniors who are in social responses and the Senior Walk that encompasses all seniors in the municipality.

Domain 2 - Heterogeneous public: measures adopted by the municipality for different groups, including the senior population.

Category 1- Habitation: measures that focus on habitation, recognizing the relevance of this factor in the citizens' quality of life. This can be translated into different assistance (technical assistance in the elaboration of architectural projects, contribution for renovations, aid for support products, financial help for rent, reduction of water and sanitation tariffs).

Category 2- Financial support: Municipal Financing Fund for Support to Private Social Solidarity Institutions for the purchase of vehicles. 
Category 3- Health: measures aimed at supporting health expenses, implemented in the reimbursement of medication and purchase of products (e.g. lenses/glasses, dental prostheses).

Category 4 - Essential goods and services: measures/actions aimed at making essential goods and services available

Domain 3 - Articulation: measures developed by the municipalities in articulation with other partners.

Category 1 - Training/Culture: Measures or initiatives for cultural and formative development of the senior population.

Category 2 - Psychosocial Support: Provision of psychosocial support to family and/or caregivers.

\section{Analysis of Results}

As already mentioned, the municipalities have expanded their administrative competences and attributions, namely in the area of social action.

One of the goals of this study is to identify the area of social action in the municipality's organic structure. The technicians working in this field are integrated into divisions (Municipality 1 - Social-educational, cultural and sports division) and within these into sectors (Municipality 1, social action and family sector).

In Ourém (Municipality 2), the Education and Healthy Life Division is in charge of the social action service, which, through the implementation of educational and social policies, aims to promote education, quality of life and well-being of the citizens.

Using the scheme constructed by the researchers as a reference, the results obtained allow us to state that municipalities predominantly implement measures aimed at different publics/residents, including senior citizens.

Within these measures, the concern with the housing area stands out. With the adoption of the support for the improvement of living conditions, the aim is to improve the functionality, comfort, and safety of people with reduced mobility, resulting from the aging process, chronic or debilitating diseases or physical/motor disabilities. This measure includes seniors when it is stated that situations of reduced mobility due to the aging process are contemplated. But people who live in isolation and / or households in vulnerable socio-economic situations are considered as recipients too.

This measure has a triple action: technical support from municipal services in the preparation of architectural projects, financial contribution for restoration, conservation and improvement; financial contribution for home adaptation and/or acquisition of support products.

This concern with living conditions is not a novelty, on the Portuguese panorama. This measure, developed by the Municipality 1 recalls a nationwide 
program named "Programa Conforto Habitacional para Pessoas Idosas (PCHI)" (Housing Comfort Program for the Elderly), created through Order No. 6716-A/2007 and which ended in 2013. Its purpose was focused on the prevention of dependency and institutionalization of older citizens, by intervening in housing qualification by improving the basic conditions of habitability and mobility of elderly people who use the Home Support Services or attend the Day Center response or whose provision of these services depends on housing qualification. The investment could take place at the building level (e.g. improvements to the roof, walls, door and window frames; creation or adaptation of spaces; improvement of existing spaces, adaptations that facilitate access to the house) but also at the level of equipment (e.g. purchase of furniture, appliances). Despite the aforementioned program having its origins in the Ministry of Social Security, it included a partnership with the municipalities, specifically with the intervention of the respective Social Networks, in a rationale of strategic intervention, participation and local management. This program, which was aimed exclusively at the elderly, began in districts considered to be the most aged, such as Bragança, Beja, Guarda, Portalegre and Vila Real. After these territories located in the interior of Portugal (from north to south), a phase II followed that included other districts.

It should be noted that housing issues were one of the first concerns of local authorities after the democratic Carnation Revolution, on the $25^{\text {th }}$ of April of 1974. The right to housing is enshrined in the Constitution of the Portuguese Republic (Article 65), recognizing its relevance in the quality of life of citizens. According to the aforementioned article $\left(2^{\circ}\right)$, it is the responsibility of the State to program and implement a housing policy. But it is also mentioned the needed collaboration between municipalities and central public administration in the construction of affordable and social houses.

The analysis carried out also allowed detection of new support in/for housing. In this case, two aspects stand. The first has to do with the fact that this measure is aimed at different populations, including seniors, since they can also be part of the recipients: individuals or families in a vulnerable economic situation. The second aspect concerns the type of support in question, which translates into a share in the amount of rent and a reduction in water, sanitation and solid waste tariffs.

Within these measures, it is also important to mention the health and financial support. The health support is materialized in the complementary support to health expenses made in pharmacies; in the co-participation in the purchase of lenses and/or frames; in the opticians located inside the municipalities; and in the co-participation in the purchase and repair of dental prostheses. 
In Municipality 2 (Ourém), we highlight the measure Municipal Financing Fund for Support to IPSS for the acquisition of vehicles. This municipality provides financial support, in the amount of 300 thousand euros, for the acquisition of new vehicles by the Private Institutions of Social Solidarity. Twenty entities were financially aided to buy a vehicle; of these, fourteen entities are related to the elderly population. This support by Ourém will be spread over 4 years, with annual charges of 74,998.68 euros.

The seniors can benefit from the provision of the essential goods and services if they are in a situation of social vulnerability, like other populations (families and isolated people). In fact, the recognition of the municipality's socioeconomic fragility and of situations of need and social emergency led to the creation of a Regulation of the Municipal Social Emergency Fund.

Support in the acquisition of essential/basic goods, through access to the social shop, is another measure that can be applied to different groups, including seniors. It should be noted that the social shops are a response widely disseminated in the national territory. In the case of Municipality 1, the Social Store is a project of intervention and social support of the Municipality "to the most in need people that, through a network of partnerships between solidary institutions, intends to promote better living conditions to people in situations of greater social vulnerability."

In Municipality 2 there is the "Banco de Ajudas Técnicas de Ourém (BATO)" (Bank of Technical Help of Ourém) which consists in providing/ lending technical assistance to people in situations of dependency and/or reduced mobility, living in the municipality.

Focusing on the measures adopted by the municipalities exclusively for the senior population, we must underline those intended to prevent isolation and promote safety in their homes: the teleassistance service. According to the regulation of this service "the beneficiaries of the teleassistance service are all those who meet, cumulatively, the following requirements: 1) Are 65 years of age or older; 2) Live alone or in permanent or temporary isolation, and/or have some degree of dependency or disability" and who live outside the urban nucleus of the municipality. "Improvement in security, self-esteem and autonomy" constitute other expressions present in the service regulation. In Municipality 2, there is also transport on demand, a transport service for the senior population, which aims to shorten distances and increase the proximity of essential services.

The identification of the elderly living alone, or isolated is the purpose of the Senior Census, a program under the responsibility of the Republican National Guard, Ministry of Internal Affairs. This program has taken place throughout the national territory since 2011, contributing to the promotion of an ambiance of greater trust between the elderly and the "Guarda Nacional Republicana (GNR)" (National Republican Guard) and to increase the feeling 
of security. The implementation of this program in a territory with low demographic density, with an ageing population, as is the case of the Municipality 1 , has proved to be very important, particularly in the identification of seniors living alone and isolated.

Relatively to the measures or activities dedicated exclusively to the senior citizens, it is possible to include activities of a social and commemorative nature. These include the organization of commemorative/ festive days/seasons, such as the International Day of the Elderly, Christmas in the nursing homes, Grandparents' Day, the Senior Carnival, and also the Senior Walk, which includes all the senior citizens of the municipality.

The municipalities assume the organization of these activities and extend to the private institutions of social solidarity of the municipalities.

Another type of activities aimed for the senior population, includes formative and cultural activities, as is the case of the senior university in Municipality 1 . The Municipality 2 offers psychosocial support to the elderly, within the scope of the cooperation protocol signed between the municipality and the health center. The technician, who is part of the Integrated Continued Care Team of Ourém, within the scope of her competencies, provides psychosocial support to users, their relatives and their caregivers.

\section{Conclusion}

This paper focuses on the competences of the local government in Portugal, in the social area, specifically in the support of the elder population.

Since the 1974 democratic revolution and the approval of the new Constitution of the Portuguese Republic (1976), that marked the beginning of the democratic regime consolidation, local authorities acquired administrative and financial autonomy. With the recognition of their autonomy, and not being subject to the management power of the central administration, the Local Power starts to define their own local administrative orientation.

This evolution reveals the gradual path of assuming competencies and attributions in various aspects, such as in the social area and aimed for different groups, like the elderly. The concern with this group is linked to the ever-growing dimension of this demographic group in Portugal, considered as "one of the countries with the highest demographic ageing" (GC, 2013, p. 10) within the European context.

The designation or expression of the ageing globalization summarizes the intensity of this phenomenon - its centrality in the contemporary societies, at the European and the global level (Leão, Ataíde, Reves, Marques \& Pontes, 2011). This phenomenon is constant throughout Portugal, with certain regions presenting a more ageing population, such as the interior of the country. This is the case of Municipality 1, strongly marked by the elderly population, but also by the depopulation, as revealed by the demographic data. 
The situation in Portugal follows European and world trends. The aging of the world population, with particular emphasis on the European population, is an unavoidable theme in scientific production and in the design of multidimensional interventions. There are several international and national organizations that prepare studies and projections that consensually point to an increase in the number of elderly people and/or the achievement of greater longevity (European Comission,2012). On January, 2019, the european population (EU-27) was estimated to be 44.8 million people, representing the elderly (65 and over) a share of 20.3 which means an increase of 0.3 points percentages compared to the previous year and 2.9 percentage points compared to 10 years before (Eurostat, 2020).

By analyzing the results, it can be concluded that the municipalities in study outline measures that directly target the senior population. It is worth highlighting Telecare in Municipality 1 and transport on demand in Municipality 2, as permanent measures; as opposed to the social and commemorative activities that take place at specific moments.

Despite some differences, the latter measures are common in both municipalities. Another aspect to underline is that there are measures aimed at seniors who may be connected to certain social responses (e.g. day center, social center, home support service) or for those who are in their respective homes, with or without family members.

Seniors can also benefit from other measures applicable to other groups, with different examples having been provided. This is the case of housing support, health support, financial support and access to basic goods and services.

Another conclusion drawn relates to the existing articulation between municipalities and other partners for the implementation/execution of measures. In the case of Municipality 1, there is the establishment of the senior university, in association with teaching institutions. In Municipality 2, there is the provision of psychosocial support to family and/or care-givers, resulting from the joint effort between the municipality and the healthcare center.

The collectivities, associative groups or private institutions of the social solidarity are partners of the local administration, in its approach to the problem of ageing population. Since the focus is on policies developed for senior citizens, the role and action of this institutions for the social support of the elderly is decisive. The type of communication and proximity that exists between local institutions and the senior citizens, is one aspect that should be studied in more detail.

The question that can be asked is about the implementation of the Social Network in support of the elderly. The other unavoidable partner is the central administration. This is the most responsible for defining public social policies for the national territory and it is determinant in the financial 
dimension (current transfers, specific programs, among others). As Ruivo (2000) states, there is a permanent relationship between the central and the local authorities, and there is space for negotiation and exchange procedures that may be fundamental for the development of the communities.

The recognition of these measures is a significant fact. However, more important than their recognition is to verify whether they really reach the elderly and whether these measures achieve their goals.

There is no doubt that it is necessary to implement and strengthen policies to protect the elderly, given the significant number of people aged 65 and over, now and in the future, in Portugal. On this subject, three final notes are highlighted:

- The indispensable cooperation between the central administration and the local administration, being clear that it is imperative the existence of a complementarity, despite their differences (Ruivo, 1990);

- The local administration must be resourceful, whether in the adoption of preventive measures, or measures focused on the treatment of problems, without having to wait for the resolution of the central authorities. It can make a difference and assume its own agenda with respect and knowledge of social realities and local networks and actors;

- Local authorities should assume a holistic view of ageing, considering it not as a problem, but as a happy ending point of human development (Fonseca, 2018). The policies adopted can contribute to the ageing process, so that older generations can continue to live in their home and community over time (Fonseca, 2018).

Although there are many references in the literature about the deep malaise, about the crisis environment in the welfare state models, explained either by the transformations imposed by globalization or by internal pressures (the nature of the European Union itself, the diversity of situations), it is also true that we capture more optimistic perspectives (Ferrera et al, 2000). There is no denying the challenges facing the state and in particular the Welfare State, but it is also true that we continue to belive in the sharing of responsibilities between the different pillars - Sate, family, market and third sector, as he believes - and in the dynamics interactions that take place between them (Esping-Andersen, 2002). It is this redistribution of functions, this logic of collective action that constitutes the challenge of the so-called policy mix (Ferrera et al, 2000). A State that takes responsibility for the design and development of social policies should not be questionable. On the contrary, the presence of this State guarantees the fight against social inequalities ( a permanent source of anomie) and may constitute a European 
response to these transformations. "The welfare state can allow people to adapt more easily to these economic changes, as well as facilitate the effort towards greater flexibility, both in the labor market and in the functioning of social protection, which has to be accompanied by a situation of safety (Ferrera et al, 2000: 21)". For this author, "the existence of social policies can potentially reduce uncertainty, help to create and stabilize collective goods, frame and mitigate social conflict and promote coordination, while reinforcing the public spirit of cooperation and trust.(2000:22).

\section{References:}

1. Associação Nacional de Municípios Portugueses (2014). Municípios de baixa densidade. Critérios aprovados pela Associação Nacional de Municípios Portugueses. Coimbra: ANMP.

2. Cardoso, M.J. F. (2012). Ação social nos Municípios Portugueses Potencialidades e Limitações. Tese de Doutoramento. Lisboa: ISCTE do Instituto Universitário de Lisboa.

3. Constituição da República Portuguesa (2015). Sétima revisão - 2005. Lisboa: Divisão de Edições AR.

4. Despacho $\mathrm{n}^{\circ}$ 6716- A/2007 do Ministério do Trabalho e Solidariedade Social (2007). Diário da República: $2^{\mathrm{a}}$ série, $\mathrm{n}^{\circ} 68$.

5. Despacho $\mathrm{n}^{\circ} 1108 / 2013$. Diário da República: $2^{\mathrm{a}}$ série, $\mathrm{n}^{\mathrm{o}} 163$.

6. Esping-Andersen, G. (1990), The Three Worlds of Welfare Capitalism, Cambridge: Polity Press.

7. European Comission (2012). The 2012 Ageing Report: economic and budgetary projecyions for the 27 EU Member States (2010-2060). European Commission, Directorate-generale for economic and financial affairs.

8. Eurostat (2020). Estrutura populacional e envelhecimento. Online publications. Obtido em 30 de abril de 2021. https://ec.europa.eu/eurostat/statistics explained/index.php?title=Population_structure_and_ageing/pt

9. Ferrera, M. (1996), 'The Southern model of welfare in social Europe', Journal of European Social Policy, vol.6, nº1,17-37.

10. Ferrera, M., Hemerijck, A. \& Rhodes, M. (2000), O Futuro da Europa Social. Oeiras: Celta Editora.

11. Fonseca, A. M. (org) (2018). Ageing in place. Boas práticas de Ageing in Place. Divulgar para valorizar. Guia de Boas Práticas. Lisboa: Fundação Calouste Gulbenkian e Universidade Católica Portuguesa.

12. Glaser, B., \& Strauss, A. (1967). The discovery of Grounded Theory Strategies for qualitative Research. Chicago: Aldine. 
13. G.C. - Gabinete dos censos 2021 (2013). Caraterização da população e das famílias a residir em Portugal, com base nos Censos de 2011. Revista de Estudos Demográficos, (51-52), 5-37.

14. Guia Prático do Programa de Conforto de Apoio Habitacional de idosos (2014). Lisboa: Instituto de Segurança Social.

15. Guillén, A. \& Palier, B. (2004). Does Europe matter? Accession to EU and Social policy developments in recent and new member states. Journal of European Social Policy, 14/3, 203-209.

16. Hemerijck, A. (2002). The self-transformation of the European social model(s)' in Esping-Andersen, Gosta et al. (eds), Why We Need a New Welfare State. Oxford: OUP.173-213.

17. Hill, C., Thompson, B., \& Williams, E. (1997). A guide to conducting consensual qualitative research. The Counseling Psychologist, 25 (4), 517-572.

18. Instituto de Habitação e da Reabilitação Urbana, I. (s.d.). ihru,i.p. Obtido em 07 de 02 de 2021, de Instituto de Habitação e da Reabilitação Urbana, I.P.:

https://www.portaldahabitacao.pt/web/guest/porta-de-entrada

19. Instituto de Habitação e da Reabilitação Urbana, I. (s.d.). IHRU,I.P. Obtido em 07 de 02 de 2021, de http://www.ihru.pt/web/guest/quemsomos

20. Leão, C., Ataíde, Â., Revés, M.; Marques, M. \& Ponte, S. (2011). A Globalização do envelhecimento - o caso português, Centro de Estudos da População, Economia e Sociedade, população e Prospetiva. Lisboa: Working Papers.

21. Lei $n^{\circ} .79 / 77$ da Assembleia da República. Diário da República: I Série, $n^{\circ} 247$.

22. Lei $\mathrm{n}^{\circ} 1 / 79$ da Assembleia da República. Diário da República: . I Série, Número I.

23. Lei n. ${ }^{\circ} 169 / 99$ da Assembleia da República (1999). Diário da República, I Série - A., n²19.

24. Lei n. ${ }^{\circ}$ 159/99 da Assembleia da República (1999). Diário da República: I série, $\mathrm{n}^{\circ} 215$.

25. Lei n. ${ }^{\circ} 75 / 2013$ da Assembleia da República (2013). Diário da República: $1^{\circ}$ série. $\mathrm{n}^{\circ} 176$.

26. Lei $n^{\circ}$ 25/85 da Assembleia da República (1985). Diário da República: I Série, $N^{\circ} 184$.

27. Lei Quadro $n^{\circ} 50 / 2018$ da Assembleia da República (2018). Diário da República: $1^{\mathrm{a}}$ série, $\mathrm{n}^{\mathrm{0}} 157$.

28. Menezes, Manuel (2002). Serviço Social Autárquico e Cidadania: a experiência da Região Centro. Coimbra: Quarteto. 
29. Mozzicafredo, J., Guerra, I., Fernandes, M.A.; Quintela, J.G.P.(1991). Gestão e legitimidade no sistema político local. Coleção estudos/3. Lisboa. Escher.

30. Município de Gouveia. (23 de setembro de 2020). Município de Gouveia. Obtido de https://www.cm-gouveia.pt/

31. Município de Ourém. (21 de setembro de 2020). Município de Ourém. Obtido de https://www.ourem.pt/

32. Pordata. (03 de setembro de 2021). Pordata. Obtido de Pordata, Base de dados: www.pordata.pt

33. Portaria no 793/89 do Ministério da Educação (1989). Diário da República: Série I n²07/89.

34. Ruivo, F. (1990). Local e Política em Portugal: o Poder Local na mediação entre Centro e Periferia. Revista Critica de Ciências Sociais, $\mathrm{n}^{\circ} 30,75-95$.

35. Ruivo, F. (2000). O Estado Labiríntico - o poder relacional entre Poderes Local e Central em Portugal. Porto: Edições Afrontamento.

36. Veneza, A. (1986). O Poder Local, 1976-1984: da indefinição á (des)centralização Estatal. Revista Critica de Ciências Sociais, $\mathrm{n}^{\circ} 18 / 19 / 20, .693-708$ 